\title{
Knowledge-intensive services and international competitiveness: a four country comparison
}

\author{
Paul Windrum \\ MERIT, University of Maastricht \\ Tongersestraat 49, PO Box 616 \\ NL-6200 MD Maastricht \\ The Netherlands \\ and \\ Mark Tomlinson \\ CRIC, University of Manchester \\ University Precinct Centre, Oxford Road \\ Manchester M13 9QH \\ UK
}

The authors would like to thank Pim den Hertog and Brigitte Preissl for their invaluable assistance in accessing national input-output tables for the Netherlands and Germany respectively. Thanks is also extended to Bart Verspagen and Bengt-Åke Lundvall for their comments on earlier drafts of the paper. As usual, all errors remain the sole responsibility of the authors. 


\begin{abstract}
The nature and consequences of services innovation remains a woefully underresearched topic. The paper calls into question two statements that are frequently repeated in the political-economic discourse on services. The first concerns the suggestion that Germany is a 'services laggard' that needs to restructure its domestic economy if it is to remain internationally competitive. By contrast, the UK is frequently held up as an example of a successfully restructured 'services economy'. The paper draws an important distinction between the quantity of services in a domestic economy and the degree of connectivity between services and other economic activities. The latter, it is argued, is far more important in determining the size of spillovers from services innovation enjoyed within a domestic economy and, hence, to international competitiveness. Particular attention is paid to the role and impact of knowledgeintensive service sectors in this regard. In addition to the UK and Germany, data is drawn from the Netherlands and Japan. Using these four comparative cases we explore the distinction between a high representation of services in the domestic economy, and the innovation spillovers facilitated by a high degree of connectivity between services and other economic sectors within a domestic economy.
\end{abstract}

Keywords: international competitiveness, knowledge-intensive services, innovation 


\section{Introduction}

Despite its increasing importance in national economies, the contribution of services to national productivity and international competitiveness remains largely unaccounted for by analysts and politicians. As Lundvall and Borrás (1999) observe, "studies of innovation processes and public action on technological development have mainly tended to focus on manufacturing activities. Services have generally been given only marginal consideration" (Lundvall and Borrás, 1998, p.117). Worse, while innovation is recognised as important for national competitiveness and economic growth, services tend to be viewed as innovative laggards that make little or no contribution to either productivity or growth. Service sectors, it is suggested, are primarily technology users which are not innovative in their own right. This view may be justified for some service industries but it is certainly not true in all cases.

A small but growing number of researchers have started to challenge this view. An important focus of their work is the relationship between knowledge-intensive service (KIS) sectors, the changing nature of the innovation process, and the globalising learning economy. This research is located in fields as diverse as innovation studies (e.g. Antonelli, 1998; Windrum, Flanagan and Tomlinson, 1997), management studies (e.g. Blackler, 1995; Quinn, 1992; Reich, 1991; Scarbrough, 1992), sciencetechnology policy studies (e.g. Hauknes, 1997; den Hertog and Bilderbeek, 1998) and regional development policy (Illeris, 1996; Keeble, Bryson and Woods, 1991). Rather than being a separate and peripheral economic factor, services form an integral part of the economic system according to these writers. It is this emphasis on the complementarity between services and manufacturing which distinguishes them from the views put forward Bell (1973), on the one hand, and by Cohen and Zysman (1987), on the other, in the post-industrial society debate ${ }^{1}$. Bell suggested that, as wealth increases, consumers are able to expand their basket of purchases beyond basic material goods to a whole new realm of services. Cohen and Zysman countered that 'manufacturing matters' and that potentially damaging consequences could follow an uncontrolled erosion of the manufacturing base.

The 'new view' of services emphasises how the traditional distinction between manufacturing and services is becoming increasingly blurred. Lundvall and Borrás detect a shift away viewing services as production and consumption 'sectors' to services as 'functions'. This change, they suggest, stems from new insights into the role of knowledge production and distribution in the economy, particularly with respect to new knowledge-based services and the reshaping of existing service activities. Quinn (1992), for example, highlights the role of strategic services in shaping competition and comparative advantages, while Reich (1991) draws attention to the role of 'technological' services and competencies in shaping new industrial

\footnotetext{
${ }^{1}$ The origins of the tertiarisation thesis can be traced back to Clark (1942) and Fuchs (1968). Lundvall and Borrás note that proponents of the thesis generally employ a stages model of economic history in which the 'service economy' represents the tertiary stage in the development of modern societies. While some writers still hold a tertiarisation perspective, the more modern literature is not limited to this view.
} 
structures and organisational patterns. Illeris (1996) extends the discussion still further, positing the location of 'advanced' or 'high quality' business services as a key factor affecting regional economic growth. In this paper we focus on the interaction between KIS firms and their clients. In addition to the direct transfer of particular knowledges between a KIS firm and its client, new knowledge is generated through the interaction itself. If this is the case, then it is possible to detect this interaction in national input-output tables. It is also possible to compare and contrast the degree of connectivity between services and non-services, and the impacts of this connectivity on productivity, across different countries.

\section{What are knowledge-intensive services?}

The term 'services' covers an extremely diverse set of economic and organisational activities. Some service firms are small, labour-intensive and have low technology inputs. Others are capital-intensive, knowledge-intensive and are major users of information and communication technologies. Market conditions also vary widely. Some service firms operate in highly specialised local market niches, with little or no competitive pressure, while others operate in highly competitive markets. As in the case of telecomms and financial services, the internationalisation of markets may be have been precipitated by a deregulation of national markets. The growth in recorded services in the advanced world economies is not simply due to the outsourcing of activities that were previously conducted in-house by manufacturers (Windrum, Flanagan and Tomlinson, 1997). As knowledge has overtaken material inputs as the key source of value added, so high-tech and highly innovative service sectors have become important to national productivity and competitiveness.

We define KIS firms as private sector organisations that rely on professional knowledge or expertise relating to a specific technical or functional domain. KIS firms may be primary sources of information and knowledge (through reports, training, consultancy etc.) or else their services form key intermediate inputs in the products or production processes of other businesses (e.g. communication and computer services). As well as being users of new technology, some KIS industries are carriers of new technology (e.g. consultancies and training services), while others are themselves integral producers of new technologies - notably the wide range of computer, software, telecomms and telematics services. Here we see a positive feedback between new technologies and new services. New technologies have spawned new service industries that have in turn played a major role in developing these technologies through laboratory, design and engineering activities. Notable examples include the KIS services connected with biotechnology, new materials, environmental technologies, and ICT. Services innovation is therefore important for the economy as a whole. A list of KIS sectors, based on research conducted by den Hertog and Bilderbeek (1998), and Windrum, Flanagan and Tomlinson (1997), is provided in Table 1 below. 


\begin{tabular}{|l|l|}
\hline Accounting and bookkeeping services & Labour recruitment and provision of technical \\
Architecture, surveying and other construction & personnel \\
services & Legal services \\
Banking and other financial services & Management consultancy \\
Computer and IT-related services (inc. & Market research \\
software) & Marketing and advertising services \\
Design services & Press and news agencies \\
Environmental services (e.g. environmental & R\&D consultancy services \\
regulation, elementary waste disposal, & Real estate \\
monitoring) & Telecommunication services \\
Facility management services & Technical engineering services \\
Insurance services & Technology-related training \\
\end{tabular}

Table 1. Knowledge-intensive service sectors

An important feature that distinguishes KIS from manufacturing firms is the type of 'product' they supply and, following this, the role they play in regional and national innovation systems. Whereas manufactured products and processes contain a high degree of codified knowledge (they are a 'commodification' of knowledge), KIS products contain a high degree of tacit ('intangible') knowledge. This point is made by Strambach (1997);

"Specialised expert knowledge, research and development ability, and problem-solving know-how are the real products of knowledge-intensive services. Given increasing differentiation and the accelerating growth of knowledge and information, indirect effects, like the early recognition of problems and more rapid adjustment to current economic and structural change, can be expected when firms succeed in utilising this external knowledge" (Strambach, 1997, p. 35).

This observation links up with Antonelli's (1988) discussion of the interaction between KIS firms and their clients. Antonelli highlights the link between new information and communication technologies (ICTs) and business-to-business KIS. $\mathrm{He}$ argues that the post-war organisational structure of vertically-integrated knowledge generation, founded on an $\mathrm{R} \& \mathrm{D}$ lab, is being replaced by an information exchange market based on real-time, on-line interactions between customers and knowledge producers. New ICTs facilitate a change in the nature of information - its divisibility, processing and communication - and the accessibility and tradability of information ${ }^{2}$. This opens up opportunities for knowledge-intensive business service firms who, Antonelli adds, tend to be the chief advocates and supporters of this emerging information market. Through ICTs, KIS companies interface between a client firm's tacit knowledge base and the wider knowledge base of the economy, improving connectivity and receptivity between the nodes of innovation networks.

\footnotetext{
${ }^{2}$ The same point has been made by Scarbrough (1997), although Scarbrough's social constructivist interpretation is notably different to Antonelli's technology-centred interpretation.
} 
KIS firms thus acquire special significance as agents who transfer experience and technologies within, and across, innovation networks. They are a 'glue' that holds the expanding learning economy together.

As well as being vehicles of knowledge transfer, KIS firms are engaged in the coproduction of new knowledge and material artefacts with their clients. This interactive problem-solving is the 'product' that clients wish to purchase. Given the importance of this interaction term, we should not overlook the factors that facilitate successful KIS-client interaction. Qualitative case studies conducted with KIS firms and their clients reveal that the quality of the provider-client interaction depends on the competences of the client as well as the KIS supplier (Windrum, Flanagan and Tomlinson, 1997). In addition to IT proficiency and other technical competences, client firms must be open to new learning contexts. Strambach (1997) suggests that knowledge adoption is facilitated by flexible, decentralised organisation structures and good quality human resource management. Cohen and Levinthal (1990) point out that a firm's absorptive capacity - its ability to assimilate new information - is closely related to its organisational routines, and the diversity (i.e. the level and distribution) of expertise within an organisation. Meanwhile Ciborra (1993) emphasises the match between new knowledge and the practices, beliefs, values, routines and cultures that lie at the heart of the organisation.

\section{Recent trends in services}

As its title suggests, the primary objective of this paper is to identify the relative contributions of KIS services to national productivity and competitiveness in four different countries; the UK, Netherlands, Germany, and Japan. An important distinction is made between a growing representation of services within one's domestic economy and an increasing level of interconnectivity between services and other economic activities. As we endeavour to show, the latter is far more important for the spillovers of services innovation enjoyed within a domestic economy.

Each of the four investigated in this paper have been selected with this point in mind. The Dutch state has, since its inception, been a predominantly trade and servicesorientated economy (Schama, 1987; Parker, 1977). The recent history of services development in the Netherlands thus provides a useful benchmark against which the other countries can be compared. The Japanese economy is similar to the UK economy in that it is founded on a combination of trade and manufacturing. However a distinguishing feature of the Japanese economy is the keiretsu system of industrial organisation that has forged close links between services and manufacturing since 1945 (Tomlinson, 1999). Of the three EU countries investigated by the paper, political support for the shift towards a services-based economy has been most pronounced in the UK. In their enthusiasm for a radical restructuring of the domestic economy, certain UK politicians and advisers have adopted the dictum that 'more services are good'. The same dictum has been advocated in Germany since the late 1980s, where it has been 
suggested that Germany is a 'services laggard' that must follow the UK example if it is to remain internationally competitive (cf. Freund et al, 1997).

The suggestion that Germany is a 'services laggard' is critically appraised in the paper, as is the suggestion that the rapid tertiarisation of the UK economy necessarily means it is benefiting most from services innovation. In this section we outline some general trends in the relative growth of KIS, and of services in general, in each of the four countries. In section 4 we outline a novel approach to estimating the impact of services innovation on national output and productivity. Using this method we report a series of statistical tests conducted on national input-output tables. A first round of tests examine the significance of services in the UK, Dutch, German and Japanese domestic economies while a second round of tests assess the significance of KIS inputs into manufacturing output.

Timeseries analyses of aggregate and sectoral data can prove useful in identifying the general growth trend of services in different national economies. Having said this, one should, as when using any technique, bear in mind the limitations of this particular mode of analysis. In this instance the main concerns are associated with the quality of the published national data, particularly the sectoral classification of services and their aggregation. We are perhaps more fortunate than previous researchers in this regard. National income accounts, and input-output tables have (finally) started to disaggregate service sector data and stopped the practice of aggregating the data into a single category labelled 'services'. This perhaps reflects a diminution of the traditional bias towards manufacturing as services come to play an increasingly important role in the national economy ${ }^{3}$.

We begin by considering the national income database provided by Eurostat (Eurostat, 1996). This database offers comparable data sets that enable us to consider the changing contributions of different economic activities to national value added in the UK, Netherlands and Germany in the period 1979-1994. Table 2 provides data on 1979 and 1994 for each main category (the complete tables containing all subcategories are provided in the appendix). Services are by far the largest contributors to national value added in each of the EU countries being considered. Indeed the share of marketed services (i.e. services that are traded in markets) in national value added increased significantly in the $1979-1994$ period, rising from $40.8 \%$ to $54.2 \%$ $(+13.4 \%)$ in the UK, from $40.2 \%$ to $51.4 \%(+11.2 \%)$ in Germany, and from $48.0 \%$ to $57.2 \%(+9.2 \%)$ in the Netherlands. The UK and Germany, starting from a lower initial base than the Netherlands, have experienced a sharper increase in the value added growth of services.

\footnotetext{
${ }^{3}$ Having said this, the bias towards manufacturing is still evident in national statistics, the recent edition of the UK 'Regional Trends' (ONS, 1997) being a case in point.
} 


\begin{tabular}{|c|c|c|c|c|c|c|}
\hline & \multicolumn{2}{|c|}{ UK } & \multicolumn{2}{|c|}{ Netherlands } & \multicolumn{2}{|c|}{ Germany } \\
\hline & 1979 & 1994 & 1979 & 1994 & 1979 & 1994 \\
\hline mio ecu & & & & & & \\
\hline Agriculture, forestry and fishing products & $\begin{array}{r}5436 \\
1.8\end{array}$ & $\begin{array}{r}13553 \\
1.6\end{array}$ & $\begin{array}{r}4094 \\
3.7\end{array}$ & $\begin{array}{r}9586 \\
3.6\end{array}$ & $\begin{array}{r}12093 \\
2.3\end{array}$ & $\begin{array}{rr}15 & 148 \\
& 1.0\end{array}$ \\
\hline Fuel and power products & $\begin{array}{r}25464 \\
8.6\end{array}$ & $\begin{array}{r}47204 \\
5.7\end{array}$ & $\begin{array}{r}9929 \\
9.0\end{array}$ & $\begin{array}{r}16145 \\
6.0\end{array}$ & $\begin{array}{r}27028 \\
5.1\end{array}$ & $\begin{array}{r}57908 \\
3.9\end{array}$ \\
\hline Manufacturing products & $\begin{array}{r}83470 \\
28.1\end{array}$ & $\begin{array}{r}167613 \\
20.2\end{array}$ & $\begin{array}{r}19871 \\
18.1\end{array}$ & $\begin{array}{r}44997 \\
16.8\end{array}$ & $\begin{array}{r}167974 \\
31.5\end{array}$ & $\begin{array}{r}365340 \\
24.6\end{array}$ \\
\hline Building and construction & $\begin{array}{r}17836 \\
6.0\end{array}$ & $\begin{array}{r}42727 \\
5.1\end{array}$ & $\begin{array}{r}7468 \\
6.8\end{array}$ & $\begin{array}{r}14740 \\
5.5\end{array}$ & $\begin{array}{r}36957 \\
6.9\end{array}$ & $\begin{array}{r}85749 \\
5.8\end{array}$ \\
\hline Market services & $\begin{array}{r}121287 \\
40.8\end{array}$ & $\begin{array}{r}450050 \\
54.2\end{array}$ & $\begin{array}{r}52758 \\
48.0\end{array}$ & $\begin{array}{r}152890 \\
57.2\end{array}$ & $\begin{array}{r}214361 \\
40.2\end{array}$ & $\begin{array}{r}763089 \\
51.4\end{array}$ \\
\hline Non-market services & $\begin{array}{r}43952 \\
14.8\end{array}$ & $\begin{array}{r}109401 \\
13.2\end{array}$ & $\begin{array}{r}15782 \\
14.4\end{array}$ & $\begin{array}{r}28923 \\
10.8\end{array}$ & $\begin{array}{r}74439 \\
14.0\end{array}$ & $\begin{array}{r}198718 \\
13.4\end{array}$ \\
\hline Total & $\begin{array}{r}297445 \\
100.0\end{array}$ & $\begin{array}{r}830548 \\
100.0\end{array}$ & $\begin{array}{r}109901 \\
100.0\end{array}$ & $\begin{array}{r}267281 \\
100.0\end{array}$ & $\begin{array}{r}532851 \\
100.0\end{array}$ & $\begin{array}{r}376378 \\
100.0\end{array}$ \\
\hline
\end{tabular}

Table 2. Contributions to national value added, 1979 and 1994:

UK, Netherlands and Germany (at 1990 prices).

Source: Eurostat (1996)

The picture for market services contrasts sharply with that of manufacturing. In the Netherlands the contribution of manufacturing to national value added fell from $18.1 \%$ in 1979 to $16.8 \%$ in $1994(-1.3 \%)$. By contrast, the contribution of manufacturing in German national value added fell from $31.5 \%$ to $24.6 \%$ (-6.9\%) in the same period. Yet even this sizeable change cannot match the (much more widely publicised) change in the structural composition of the UK economy. There the manufacturing contribution to value added fell from $28.1 \%$ in 1979 to $20.2 \%$ in 1994 $(-7.9 \%)$ !

Manufacturing is not the only category whose contribution to national value added declined between 1979 and 1994. Indeed the relative contributions of all categories except market services has declined in each country. The data suggests a tertiarisation of these three EU economies since 1979. Tertiarisation appears to have been least pronounced in the Netherlands. Having said this, we note the much higher starting base of services in the Netherlands. Furthermore, the services contribution to national value added is higher than the UK and Germany. Tertiarisation appears to have been particularly rapid in the UK, lending support to the suggestion that the UK has become a 'service economy' - or, more accurately, a 'services-dominated economy'. Perhaps the most surprising findings are those for Germany, where the degree of tertiarisation appears to have been almost equal to that experienced in the UK. The oft-noted claim that the German economy is a 'services laggard' is certainly not supported by the national income data. 
Examining the sub-categories of market services listed in the Eurostat data sets produces some other interesting findings. The KIS sectors identified in Table 1 are present in three Eurostat sub-categories: 'communication services', 'finance and insurance services', and 'other market services'. The data on these sub-categories is presented in Table 3 below $^{4}$. Of all the marketed services listed by Eurostat, 'finance and insurance services' and 'other market services' have contributed most to the tertiarisation of the UK, German and Dutch economies. Adding these to 'communication services', the combined contribution of KIS firms to national value added has risen from $29.5 \%$ to $37.5 \%(+8 \%)$ in the Netherlands, from $22.1 \%$ to $34.7 \%$ $(+12.6 \%)$ in the UK, and from $24 \%$ to $36 \%(+12 \%)$ in Germany. As before, the Netherlands began from a higher initial base and, while experiencing a slower rate of growth, continues to have the highest concentration of these service activities. The data suggests that KIS growth has been most pronounced in the UK. The Eurostat data suggests that the growth of KIS in Germany has paralleled that of the UK. Indeed the data indicates that the contribution of KIS to national value added are actually higher in Germany than in the UK.

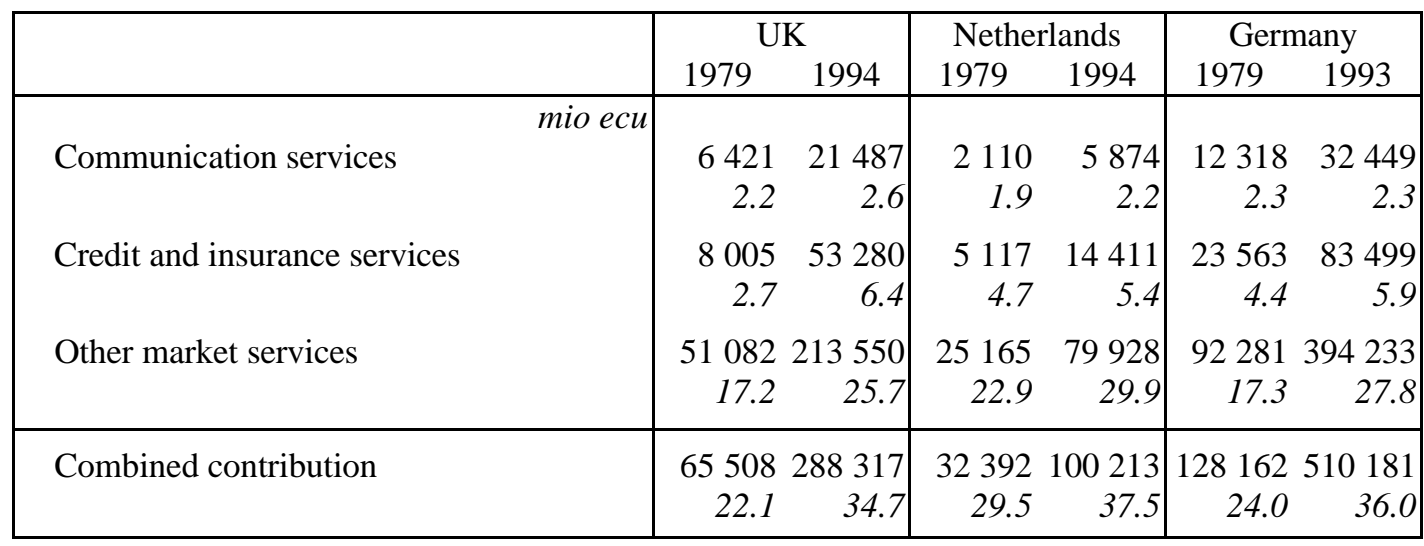

Table 3. Contribution of knowledge-intensive service sectors to national value added: UK, Netherlands and Germany (at 1990 prices).

Source: Eurostat (1996)

Given the highly aggregated nature of the data sets, there is little more that can be done with the Eurostat national income accounts. We therefore turn to data provided by national input-output tables. National input-output tables are a particularly useful source for identifying the extent to which knowledge-intensive services, and indeed services in general, are integrated within a domestic national economy. In section 4 we analyse the input-output tables provided by the respective national statistical offices. Before that, we again make use of comparable data sets, this time provided by the OECD (OECD, 1995), to draw an initial set of cross-country comparisons. Once again we focus on services categories that contain a high representation of the KIS activities identified in Table 1,. In the OECD tables these are, respectively, 'communications' (ISIC 72), 'finance and insurance' (ISIC 81 and 82), and 'real

\footnotetext{
${ }^{4}$ Unfortunately Eurostat does not provide 1994 data on these categories for Germany. Therefore we list the 1993 data for Germany.
} 
estate and business services' (ISIC 83) ${ }^{5}$.

Figure 1 plots the share of KIS sectors as a percentage of intermediate inputs to all domestic sectors in the UK, Germany, Netherlands and Japan. Two points are of particular interest here. Firstly, while the OECD tables do not provide data for Germany prior to 1980, the representation of KIS in Germany was much higher than the UK, Netherlands and Japan between 1980 and 1990. Once more this brings into serious doubt the suggestion that Germany is a 'services laggard'. Secondly, there is a striking difference between the relative growth of KIS across the four countries. The Netherlands initially started from highest base but have experienced the slowest relative growth in KIS sectors. The most striking change has been in the UK, where KIS appear to have been growing at an exponential rate between 1970 and 1990. By contrast the Netherlands, Germany and Japan have experienced a more gradual (linear) growth in KIS. This finding supports the claim that the UK underwent a radical restructuring of its domestic economy during the 1980s.

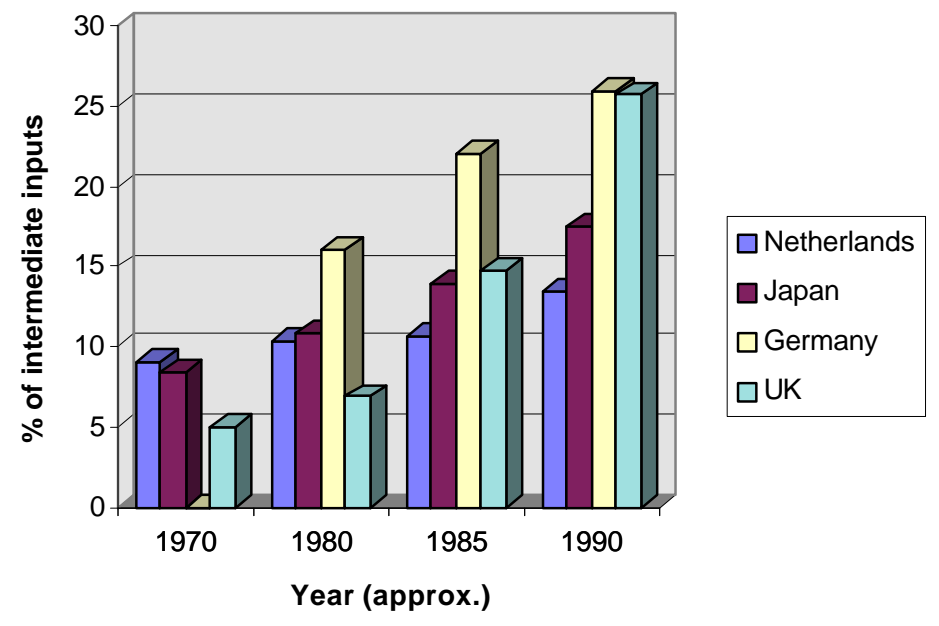

Figure 1. Knowledge-intensive service sectors as a percentage of intermediate inputs to all sectors

Source: OECD (1995)

Widening the analysis to include all services categories, one can examine the extent to which service activities are inter-linked with the rest of the domestic economy. Analysing the changing shares within and between sectors over time provides an important insight into the comparative evolution of different economic systems. Here we shall simply distinguish between services and non-services (agriculture, construction and manufacturing) in each of the four counties (Table 4 below).

Examining the OECD data yields a number of interesting results. Firstly, the services

\footnotetext{
${ }^{5}$ The bundling of business services - a significant proportion of which will be business-to-business KIS - with real estate in a single ISIC category is unfortunate. However this is an improvement over the Eurostat category 'other market services', which includes hairdressers and other personal services.
} 
share of total intermediary inputs has increased in all four countries. This is again indicative of a trend towards the tertiarisation of the domestic UK, Dutch, German and also Japanese economies. Second, the strength of this trend is found to differ significantly between the respective countries. Again the data suggests that the trend has been most pronounced in the UK and least pronounced in the Netherlands which, as noted previously, was already a services-dominated economy by the early 1970s. It is the extent to which this change has occurred in the UK which is again so remarkable. In fact the total proportion of intermediate domestic flows accounted for by services (services to services plus services to non-services) doubled in the UK, rising from $22.8 \%$ in 1968 to $44.5 \%$ in 1990! Over the same period, the total proportion of intermediate domestic flows accounted for by services in Japan rose from $23.9 \%$ to $38.2 \%$, while the services share of domestic intermediate inputs in the Netherlands rose from $21.0 \%$ to $23.1 \%$.

\begin{tabular}{|c|lll|}
\hline \multicolumn{4}{|c|}{ Netherlands } \\
\hline \multirow{2}{*}{1972} & & Services & Non-Services \\
& Services & $11.1 \%$ & $9.9 \%$ \\
& Non-Services & $10.1 \%$ & $69.0 \%$ \\
\hline \multirow{2}{*}{1977} & & Services & Non-Services \\
& Services & $11.2 \%$ & $9.3 \%$ \\
& Non-Services & $8.5 \%$ & $71.0 \%$ \\
\hline \multirow{2}{*}{1981} & & Services & Non-Services \\
& Services & $12.2 \%$ & $10.4 \%$ \\
& Non-Services & $8.5 \%$ & $69.0 \%$ \\
\hline \multirow{2}{*}{1986} & & Services & Non-Services \\
& Services & $12.7 \%$ & $10.4 \%$ \\
& Non-Services & $8.3 \%$ & $68.5 \%$ \\
\hline
\end{tabular}

\begin{tabular}{|c|lll|}
\hline \multicolumn{4}{|c|}{ UK } \\
\hline \multirow{2}{*}{1968} & & Services & Non-Services \\
& Services & $8.7 \%$ & $14.1 \%$ \\
& Non-Services & $7.7 \%$ & $69.5 \%$ \\
\hline \multirow{2}{*}{1979} & & Services & Non-Services \\
& Services & $11.2 \%$ & $15.4 \%$ \\
& Non-Services & $10.7 \%$ & $62.7 \%$ \\
\hline \multirow{2}{*}{1984} & & Services & Non-Services \\
& Services & $14.5 \%$ & $13.5 \%$ \\
& Non-Services & $11.9 \%$ & $60.1 \%$ \\
\hline \multirow{2}{*}{1990} & & Services & Non-Services \\
& Services & $28.9 \%$ & $15.6 \%$ \\
& Non-Services & $12.8 \%$ & $42.7 \%$ \\
\hline
\end{tabular}

\begin{tabular}{|c|lll|}
\hline \multicolumn{4}{|c|}{ Japan } \\
\hline \multirow{2}{*}{1970} & & Services & Non-Services \\
& Services & $8.9 \%$ & $15.0 \%$ \\
& Non-Services & $8.4 \%$ & $67.7 \%$ \\
\hline \multirow{2}{*}{1980} & & Services & Non-Services \\
& Services & $11.4 \%$ & $17.2 \%$ \\
& Non-Services & $9.0 \%$ & $62.4 \%$ \\
\hline \multirow{2}{*}{1985} & & Services & Non-Services \\
& Services & $14.1 \%$ & $17.5 \%$ \\
& Non-Services & $9.3 \%$ & $59.1 \%$ \\
\hline \multirow{2}{*}{1990} & & Services & Non-Services \\
& Services & $18.8 \%$ & $19.4 \%$ \\
& Non-Services & $10.7 \%$ & $51.1 \%$ \\
\hline
\end{tabular}

\begin{tabular}{|c|c|c|c|}
\hline \multicolumn{4}{|c|}{ Germany } \\
\hline 1970 & $\begin{array}{l}\text { Services } \\
\text { Non-Services }\end{array}$ & Services & $\begin{array}{l}\quad \text { Non-Services } \\
\text { Data not } \\
\text { available } \\
\end{array}$ \\
\hline 1980 & $\begin{array}{l}\text { Services } \\
\text { Non-Services }\end{array}$ & $\begin{array}{l}\text { Services } \\
13.2 \% \\
10.1 \% \\
\end{array}$ & $\begin{array}{l}\text { Non-Services } \\
15.6 \% \\
61.1 \% \\
\end{array}$ \\
\hline 1985 & $\begin{array}{l}\text { Services } \\
\text { Non-Services }\end{array}$ & $\begin{array}{c}\text { Services } \\
16.6 \% \\
9.8 \% \\
\end{array}$ & $\begin{array}{l}\text { Non-Services } \\
17.4 \% \\
56.2 \% \\
\end{array}$ \\
\hline 1990 & $\begin{array}{l}\text { Services } \\
\text { Non-Services }\end{array}$ & $\begin{array}{l}\text { Services } \\
20.0 \% \\
4.5 \% \\
\end{array}$ & $\begin{array}{l}\text { Non-Services } \\
19.4 \% \\
51.1 \% \\
\end{array}$ \\
\hline
\end{tabular}

Table 4. Intermediate flows of services and non-services (as a \% of total): Netherlands, UK, Japan and Germany.

Source: OECD (1995)

Unfortunately the OECD tables do not provide data on Germany for the 1970s. Still, the data provided for 1980 onwards makes for interesting reading. We observed from diagram 1 that the representation of KIS sectors in the German domestic economy was consistently higher than in the other three countries between 1980 and 1990 . Examining the data for all the services categories, we find that the services share of intermediary inputs in Germany stood at $28.8 \%$ in 1980 - higher than the Netherlands (20.5\%), the UK (26.6\%) and Japan (28.6). By 1990 the figure stood at 39.4\%. This remains second only to the UK which, as the OECD data again indicates, has 
experienced an incredibly high degree of tertiarisation. With regards to the German domestic economy, findings drawn from OECD data support, and lend further weight to, the findings drawn the Eurostat data. Both data sets seriously call into doubts the suggestion that Germany is a 'services laggard'. Not only did the national share of services grown significantly between 1970 and 1990 but inter-sectoral flows from services to non-services also strengthened during this period.

The distinction between service to service flows on the one hand, and service to nonservice flows on the other, leads to a fourth important finding. Whereas the overall growth of services in intermediary goods can be attributed to growth in both service to service and service to non-service flows in the Netherlands, Japan and Germany, the same cannot be said of the UK. There the share of services to non-services has remained almost constant (rising from $14.1 \%$ in 1968 to $15.6 \%$ in 1990), with the doubling of the total services share in intermediate transactions almost entirely due to the dramatic increase in services to services flows. Starting from the lowest initial base, the service to service share of intermediate flows rose from $8.7 \%$ in 1968 to $28.9 \%$ in 1990 - an increase of $232 \%$ ! The share of service to service flows in the UK far exceeds that found in Germany $(20.0 \%)$, Japan $(18.8 \%)$ or the Netherlands $(12.7 \%)$. Given the low level of non-service to service flows indicated by the data, a rather disturbing trend appears to be taking place in the UK. Distinct clusters of service activities appear to be forming. What is more, these seem to have very weak linkages with (equally distinct) clusters of non-service activities. In effect, there appears to be two distinct islands of economic activity. This is likely to seriously limit the spillover effects of innovation in knowledge-intensive services. It is to this issue that we turn next.

\section{Measuring the impact of knowledge-intensive services on national output and productivity}

As previously stated, the central aim of this paper is to examine the extent to which knowledge-intensive services enhance national productivity through their interaction with all other economic sectors. The conventional procedure is to test some form of aggregate production function, usually of a Cobb-Douglas variety, that contains capital and labour inputs. Unfortunately there are both practical and theoretical problems in adopting this approach. To begin with, while data for labour is readily available, obtaining data on the consumption of fixed capital is far more problematic. Furthermore, even if such data were readily available, there are theoretical problems associated with the construction of aggregate production functions containing capital (cf. Harcourt and Laing, 1971; Steedman, 1979).

An alternative course of action is to construct a labour-based production function in which labour interacts with two types of intermediate goods; material and knowledge. As Georgescu-Roegen (1971) observed, the process of production is concerned with the application of labour and knowledge to inanimate matter, subject to the laws of entropy. This approach to the study of national competitiveness is not new of course, 
but harks back to Ricardo's original formulation of the theory of comparative advantage (see Taussig, 1939 for a classic treatment of Ricardian international trade theory). Here we formulate two versions of a labour-based production function that will be used to test the national input-output data provided by the Dutch CBS (CBS, 1994), the German SB (SB, 1997) and British ONS (ONS, 1995) respectively. We shall consider the less detailed OECD data for Japan (OECD, 1995). The OECD tables report a total of 35 sectors for the Japanese economy. By contrast, the CBS input-output tables report a total of 92 sectors for the Netherlands, the SB tables a total of 58 sectors for Germany, and the ONS tables a total of 123 sectors for the UK. The KIS sectors reported in the respective data sets are listed in Table 5. Variation is due to differences in the level of disaggregation found in these national data sets.

\begin{tabular}{|c|c|}
\hline $\begin{array}{l}\text { UK (ONS data) } \\
\text { postal services } \\
\text { telecomms } \\
\text { banking and finance } \\
\text { aux. finance } \\
\text { insurance } \\
\text { real estate agents } \\
\text { legal services } \\
\text { accounting } \\
\text { other professional services } \\
\text { advertising } \\
\text { computer services } \\
\text { other business services }\end{array}$ & $\begin{array}{l}\text { Netherlands (CBS data) } \\
\text { post and telecomms } \\
\text { banking } \\
\text { financial services } \\
\text { insurance } \\
\text { real estate agencies } \\
\text { letting services } \\
\text { legal, accounting and business services } \\
\text { computer services } \\
\text { advertising agencies } \\
\text { general business services } \\
\text { employ. agencies \& recruitment services }\end{array}$ \\
\hline $\begin{array}{l}\text { Germany (SB data) } \\
\text { post and telecomms } \\
\text { banking and financial services } \\
\text { insurance } \\
\text { real estate agencies } \\
\text { science and culture, and publishing } \\
\text { business services } \\
\text { other business services }\end{array}$ & $\begin{array}{l}\text { Japan (OECD data) } \\
\text { communication services } \\
\text { financial and insurance services } \\
\text { real estate agencies } \\
\text { business services }\end{array}$ \\
\hline
\end{tabular}

Table 5. KIS sectors recorded in national income-output data

Details of the derivation of the production functions we use is provided in the appendix. We estimate two equations:

$$
\begin{aligned}
& \log \mathrm{Q}=\log \mathrm{A}+\mathrm{a}_{1} \log \mathrm{M}+\mathrm{b}_{1} \log \mathrm{K}+\mathrm{c}_{1} \log \mathrm{L} \\
& \log \mathrm{Q} / \mathrm{L}=\log \mathrm{A}+\mathrm{a} \log (\mathrm{M} / \mathrm{L})+\operatorname{blog}(\mathrm{K} / \mathrm{L})
\end{aligned}
$$

where $\mathrm{Q}$ is gross output, $\mathrm{M}$ is the material (manufactured) input, $\mathrm{K}$ is the KIS input, and $\mathrm{L}$ is the labour input in each sector. Each country is considered separately. A, $\mathrm{a}_{1}$, $b_{1}$, and $c_{1}$ are estimated and provide a measure of the impact of the various inputs on output and productivity. Thus model 1 estimates gross output in each sector as a function of $\mathrm{M}, \mathrm{K}$ and $\mathrm{L}$, while model 2 estimates a productivity measure $(\mathrm{Q} / \mathrm{L})$ that is a function of $\mathrm{M} / \mathrm{L}$ and $\mathrm{K} / \mathrm{L}$. 
Running model 1 on 1990 input-output data for the UK, 1993 data for Germany and 1994 data for the Netherlands, we find the estimated coefficients on K, M and L variables to be statistically significant at the $1 \%$ level (see Table 6 below). We note that the L coefficient is not significant at the $1 \%$ or $5 \%$ level for Japan. This may be due to the less detailed nature of the OECD data used for Japan. The estimated coefficients for $\mathrm{M}$ and $\mathrm{K}$ are particularly revealing. The estimated values on the impacts of purchased intermediate material goods (M) are very similar across UK, Netherlands and Japan. The impacts of intermediate material goods are lower in Germany, although this is made up by the exploitation of KIS, which is second only to Japan. Indeed the estimated values for KIS (K) differ considerably. The estimated coefficient for Japan is far higher than the estimated UK coefficient, with the estimates for Germany and the Netherlands lying between these two. This suggests that, while the Japanese and Dutch economies have lower absolute shares of KIS in national output compared to the UK, they are being exploited more effectively within their respective national economic systems. The German system, with the highest absolute share of KIS in all four countries (Figure 1 above), is also exploiting these more effectively than the UK system.

\begin{tabular}{|l|cccc|}
\hline Coefficient & UK & Netherlands & Germany & Japan \\
\hline $\mathrm{M}$ & $0.382(.031)$ & $0.363(.038)$ & $0.204(.058)$ & $0.378(.028)$ \\
$\mathrm{K}$ & $0.195(.029)$ & $0.280(.064)$ & $0.293(.098)$ & $0.518(.071)$ \\
$\mathrm{L}$ & $0.387(.038)$ & $0.301(.059)$ & $0.328(.086)$ & $0.113(.077)$ \\
Constant & $1.933(.212)$ & $2.413(.217)$ & $3.389(.390)$ & $1.956(.154)$ \\
$\mathrm{R}^{2}$ & .96 & .91 & .91 & .98 \\
$\mathrm{~N}$ & 121 & 90 & 56 & 33 \\
F statistic & 822.415 & 306.408 & 172.271 & 605.452 \\
\hline
\end{tabular}

Table 6. Estimated statistics for model 1: UK, Netherlands, Germany and Japan.

Estimating model 2 on the same series of national input-output data for the UK, Germany, Netherlands and Japan we find each of the estimated coefficients on K/L and $\mathrm{M} / \mathrm{L}$ are statistically significant at the $1 \%$ level (see Table 7 below). The productivity patterns suggested by these results add weight to the first set of statistical tests. The estimated coefficients for $\mathrm{M} / \mathrm{L}$ suggest that productivity due to manufactured inputs is very similar across the four counties, ranging from 0.339 to 0.409. However the estimated coefficients for $\mathrm{K} / \mathrm{L}$ suggest productivity due to knowledge-intensive services differs greatly between the four countries, ranging from 0.512 to 0.183 . The estimated values for Japan, Germany and the Netherlands are much higher than the UK estimate. 


\begin{tabular}{|l|cccc|}
\hline Coefficient & UK & Netherlands & Germany & Japan \\
\hline $\mathrm{M} / \mathrm{L}$ & $0.409(.026)$ & $0.386(.036)$ & $0.339(.574)$ & $0.372(.024)$ \\
$\mathrm{K} / \mathrm{L}$ & & & & \\
& $0.183(.028)$ & $0.302(.063)$ & $0.289(.114)$ & $0.516(.071)$ \\
constant & & & & \\
& $1.681(.038)$ & $2.048(.075)$ & $1.725(.127)$ & $2.027(.083)$ \\
$\mathrm{R}^{2}$ & .72 & .71 & .58 & .91 \\
$\mathrm{~N}$ & 121 & 90 & 56 & 33 \\
F statistic & 153.335 & 104.706 & 37.063 & 144.019 \\
\hline
\end{tabular}

Table 7. Estimated statistics for model 2: UK, Netherlands, Germany and Japan.

\section{Conclusions}

The findings of this paper call into question two oft-repeated statements in the politicaleconomic discourse on services. The first is the suggestion that Germany is a services laggard. Of the countries considered here, services growth in Germany is second only to the UK. What is more, the data suggest that the impact of KIS on German output and productivity is higher than the UK. A second, more general, message which emerges is the need to distinguish between a general increase in the representation of services within a national economy, and the degree of integration between services and other economic activities. This is especially clear in the case of the UK. While the UK experienced a remarkable growth of service activities during the 1980s, this has less of an impact on manufacturing and other non-service sectors in the domestic UK economy. Consequently the economy-wide benefits of services innovation are actually lower than in the other countries which we have considered. It is particularly striking that Japan enjoys the highest spillover effects from services innovation, and that this is due to stronger flows of useful knowledge and information from services to other activities. The data suggest that there are now two distinct islands of economic activity in the UK - services and non-services - which have very weak linkages. The situation is very different in Japan, the Netherlands and Germany. If, as other writers have argued, KIS play an important role in linking together different parts of a knowledge economy, then one must ask what and whom are they linking together?

The aggregate data examined in this paper cannot, in isolation, provide an explanation of why these patterns have emerged. However a number of possible factors are suggested by the data, highlighting the need for further research. For example, lower estimated spillovers from KIS in the UK, combined with the observation that UK services generally appear to be taking on a dynamic of their own, suggests that researchers need to revisit the interface between services and manufacturing. Economic historians of the Industrial Revolution are consistently at pains to point out that the birth of the manufacturing economy in the UK was made possible by the Agricultural Revolution which preceded it. The dramatic gains in agricultural productivity made during the agrarian revolution released the large quantities of 
labour necessary for industrialisation to occur. What is more, a close structural relationship formed between manufacturing and agriculture during the early phases of the industrial revolution; a relationship that was beneficial to both parties (cf. Matthias, 1996). The manufacture of improved agricultural implements and the development of new forms of mechanisation improved both the quantity and quality of the agricultural outputs used by manufacturers. The results presented in this paper suggest that a parallel situation may now exist between services and manufacturing. If, as is suggested, these national economies are shifting towards a 'services economy' model, analysts should avoid judging relative success or failure by the degree to which one type of activity replaces another. The findings of this paper suggest that those national economies who are benefiting most from this transition are those which have strong, mutually beneficial, links between services and other economic activities, most notably manufacturing.

This leads us to a further issue requiring investigation: the manner by which different organisational structures incorporate different inputs into the production process. While the data considered in this paper is highly aggregated, it highlights the extent to which knowledge and material inputs are used differently in the four countries and also the very different levels of interaction between services and manufacturing. This raises some important questions for management policy. Given these differences, a qualitative distinction needs to be drawn between the way in which client firms consume and exploit KIS services. We know, from various studies, that quite different networking cultures are to be found in different countries (e.g. Lundvall, 1992; Nelson, 1993). Given the higher levels of productive interaction identified in the Japanese data, analysts should consider those factors that distinguish it from the UK, Germany and the Netherlands. As Tomlinson (1999) points out, there is a wellestablished tradition of highly integrated networks in Japan - the keiretsu form of industrial organisation - that is frequently cited as being an important source of Japanese competitive advantage. These co-operative networks, which typically contain a range of manufacturing and service firms, appear to facilitate a high return to the consumption of KIS. This suggests that managers elsewhere should look carefully at the way in which they interact with their KIS providers. The effective consumption of intangible services requires the adoption of a process-orientated perspective in which close interaction is fostered with the service provider. In addition to complementary knowledge and technical competences, the quality of interaction depends on the practices, beliefs, values, routines and culture of the client organisation. If the use of these KIS services is to be encouraged then trust must be built up across the client organisation. Herein lies an important research agenda to be addressed in future work. 


\section{Bibliography}

Antonelli, C., 1998, Localized technological change, new information technology and the knowledge-based economy: the European evidence, Journal of Evolutionary Economics, 8, pp.177-198.

Bell, D., 1973, The Coming of the Post-Industrial Society, Heinemann: London.

Blackler, F., Knowledge, knowledge work and organizations: an overview and interpretation, Organization Studies, 1995, 16, pp.1021-1046.

CBS, 1994, Input-Output Tables, Netherlands Statistics: Voorburg/Heerlen (NL).

Ciborra, C.U., 1993, Teams, Markets, Systems: Business Innovation and Information Technology, Cambridge University Press: Cambridge.

Clark, C., 1942, The Conditions of Economic Progress, Macmillan: London.

Cohen, S.S. and Zysman, J., 1987, Manufacturing Matters: the Myth of the PostIndustrial Economy, Basic Books: New York.

Cohen, W.M. and Levinthal, D.A., 1990, Absorptive capacity: a new perspective on learning and innovation, Administrative Science Quarterly, 35, pp.128-152.

Eurostat, 1996, National Accounts 1970-1994, Eurostat: Brussels, Luxembourg.

Freund, B., Konig, H. and Roth N., 1997, Impact of information technologies on manufacturing, International Journal of Technology Management, 13:3, pp.215-228.

Fuchs, V., 1968, The Service Economy, NBER/Columbia University Press: Columbia.

Georgescu-Roegen, N., 1971, The Entropy Law and the Economic Process, Harvard University Press: Cambridge, Mass.

Harcourt, G.C. and Laing, N., 1971, Some Cambridge Controversies in the Theory of Capital, Penguin: London.

Hauknes, J., 1997, 'Services in innovation systems - Do they have a role to play?', in Miles, I. (ed.), Services, Innovation and the Knowledge-based Economy, forthcoming.

den Hertog, P. and Bilderbeek, R., 1998, Innovation in and through knowledge intensive business services in the Netherlands, TNO-report STB/98/03, TNO/STB 1997.

Illeris, S., 1996, The Service Economy - A Geographical Approach, John Wiley: London.

Keeble, D., Bryson, J., and Woods, P.A., 1991, Small firms, business service growth and regional development in the UK: some empirical findings, Regional Studies, 25, pp.439-458. 
Lundvall, B-Å., 1992, National Systems of Innovation, Frances Pinter: London

Lundvall, B-Å and Borrás, S., 1998, The globalising learning economy: implications for innovation policy, TSER Programme Report, DG XII, Commission of the European Union.

Matthias, P., 1996, Agriculture and Industrialisation: From the Eighteenth Century to the Present, Blackwell: Oxford.

Nelson, R. (ed.), 1993, National Innovation Systems: A Comparative Analysis, Oxford University Press: Oxford

OECD, 1995, The OECD Input-Output Database, OECD: Paris.

ONS, 1995, 1990 Input-Output Tables for the UK, Office for National Statistics: London.

ONS, 1997, Regional Trends, Office for National Statistics: London.

Parker, G., 1977, The Dutch Revolt, Penguin: London.

Quinn, J. B., 1992, Intelligent Enterprise, Free Press: New York.

Reich, R., 1991, Work of Nations - Preparing Ourselves for 21st Century Capitalism, Simon Schuster.

SB, 1997, Input-Output-Tabellen 1993, Volkswirtschaftliche Gesamtrechnungen, Fachserie 18, Reihe 2, Statistisches Bundesamt: Wiesbaden.

Scarbrough, H., (ed.), 1992, The IT Challenge: Strategy and IT in Financial Services, Prentice-Hall: London.

Scarbrough, H., 1997, Making the matrix matter: strategic information systems in financial services, Journal of Management Studies, 34, pp.171-190.

Schama, S., 1987, The Embarrassment of Riches, Knopf: New York.

Steedman, I., 1979, Fundamental Issues in Trade Theory, Macmillan: London.

Strambach, S., 1997, Knowledge-intensive services and innovation in Germany, Report for TSER project, University of Stuttgart.

Taussig, F.W., 1939, Principles of Economics, Vol.1, Macmillan: London.

Tomlinson, M., 1999 (forthcoming), 'Information and technology flows from the service sector: A UK-Japan comparison', in Miles, I. and Boden, M. (eds.), Services, Innovation and the Knowledge-Based Economy, Cassell.

Windrum, Flanagan and Tomlinson, 1997, Recent patterns of services innovation in the UK, Report for TSER project 'SI4S', PREST: Manchester. 


\section{Technical Appendix}

In the first version of the labour-based production function we shall assume that labour interacts with intermediate manufactured goods consumed in the production process on the one hand, and knowledge intensive services on the other. Output $\mathbf{Q}$ is therefore a function of $\mathbf{M L}$ and $\mathbf{K L}$, where $\mathbf{M}$ is the quantity of intermediate manufactured goods purchased, $\mathbf{L}$ is the wage bill of the sector and $\mathbf{K}$ is the quantity of knowledge-intensive services purchased.

$$
\mathrm{Q}=\mathrm{A}(\mathrm{ML})^{\mathrm{a}}(\mathrm{KL})^{\mathrm{b}}
$$

rewriting in logs we obtain

$$
\log \mathrm{Q}=\log \mathrm{A}+\mathrm{a} \log \mathrm{M}+\mathrm{b} \log \mathrm{K}+\mathrm{c} \log \mathrm{L}
$$

where $c=(a+b)$

One can relax the assumption that the interaction of $\mathrm{L}$ with $\mathrm{M}$ and $\mathrm{K}$ is restricted as follows,

assume $\quad \mathrm{Q}=\mathrm{A}\left(\mathrm{M}^{\mathrm{a} 1} \mathrm{~L}^{\mathrm{a} 2}\right)\left(\mathrm{K}^{\mathrm{b} 1} \mathrm{~L}^{\mathrm{b} 2}\right)$

then $\quad \log \mathrm{Q}=\log \mathrm{A}+\mathrm{a}_{1} \log \mathrm{M}+\mathrm{b}_{1} \log \mathrm{K}+\mathrm{c}_{1} \log \mathrm{L}$

where $c_{1}=\left(a_{2}+b_{2}\right)$

This equation provides the basis for the first model to be estimated. Note that equation $1 \mathrm{a}$ is a special case of equation $1 \mathrm{~b}$ where $\mathrm{a}_{1}=\mathrm{a}_{2}$ and $\mathrm{b}_{1}=\mathrm{b}_{2}$.

One can also extend the analysis of labour interaction to examine the relative productivity gains due to knowledge-intensive services in the different countries under review. The second model to be tested here takes the form of;

$$
\mathrm{Q} / \mathrm{L}=\mathrm{A}(\mathrm{M} / \mathrm{L})^{\mathrm{a}}(\mathrm{K} / \mathrm{L})^{\mathrm{b}}
$$

which, rewriting in logs, gives

$$
\log \mathrm{Q} / \mathrm{L}=\log \mathrm{A}+\operatorname{alog}(\mathrm{M} / \mathrm{L})+\operatorname{blog}(\mathrm{K} / \mathrm{L})
$$




ECONOMIC ACTIVITIES
Agriculture, forestry and fishing products
Fuel and power products
Manufacturing products
Building and construction
Market services
Recovery and repair, wholesale and retail services
Lodging and catering services
Inland transport services
Maritime and air transport services
Auxiliary transport services
Communication services
Credit and insurance services
Other market services
Non-market services
General government services
Other non-market services
TOTALS OF SECTORS
Imputed output of bank services
Gross value added at market prices

\begin{tabular}{|c|c|c|c|c|c|c|c|c|c|c|c|c|c|c|c|}
\hline $\begin{array}{r}5436 \\
1.8\end{array}$ & $\begin{array}{r}465 \\
1.7\end{array}$ & $\begin{array}{r}8079 \\
1.8\end{array}$ & $\begin{array}{r}9031 \\
1.9\end{array}$ & $\begin{array}{r}8184 \\
1.6\end{array}$ & $\begin{array}{r}10167 \\
1.9\end{array}$ & $\begin{array}{r}9196 \\
1.6\end{array}$ & $\begin{array}{r}8807 \\
1.6\end{array}$ & $\begin{array}{r}9065 \\
1.6\end{array}$ & $\begin{array}{r}9339 \\
1.4\end{array}$ & $\begin{array}{r}10833 \\
1.4\end{array}$ & $\begin{array}{r}11292 \\
1.5\end{array}$ & $\begin{array}{r}11410 \\
1.5\end{array}$ & $\begin{array}{r}11892 \\
1.5\end{array}$ & $\begin{array}{r}12499 \\
1.6\end{array}$ & $\begin{array}{r}13553 \\
1.6\end{array}$ \\
\hline $\begin{array}{r}5464 \\
8.6\end{array}$ & $\begin{array}{r}266 \\
9.6\end{array}$ & $\begin{array}{l}498 \\
10.8\end{array}$ & 645 & $\begin{array}{r}59325 \\
11.7\end{array}$ & $\begin{array}{r}7251 \\
10.7\end{array}$ & $\begin{array}{r}62950 \\
10.7\end{array}$ & $\begin{array}{r}4664 \\
8.1\end{array}$ & $\begin{array}{r}4332 \\
7.6\end{array}$ & 5350 & $\begin{array}{r}46339 \\
6.2\end{array}$ & $\begin{array}{r}43163 \\
5.7\end{array}$ & $\begin{array}{r}47800 \\
6.1\end{array}$ & $\begin{array}{r}45167 \\
5.8\end{array}$ & $\begin{array}{r}44908 \\
5.8\end{array}$ & $\begin{array}{r}47204 \\
5.7\end{array}$ \\
\hline $\begin{array}{r}83470 \\
28.1\end{array}$ & & $\begin{array}{l}851 \\
24.9\end{array}$ & & $\begin{array}{r}9457 \\
23.6\end{array}$ & $\begin{array}{r}r 119 \\
23.6\end{array}$ & $\begin{array}{r}9309 \\
23.8\end{array}$ & & $\begin{array}{r}9455 \\
24.0\end{array}$ & $\begin{array}{r}4527 \\
24.0\end{array}$ & $\begin{array}{r}3297 \\
23.2\end{array}$ & 6326 & $\begin{array}{r}64024 \\
20.8\end{array}$ & & $\begin{array}{r}56551 \\
20.2\end{array}$ & $\begin{array}{r}67613 \\
20.2\end{array}$ \\
\hline $\begin{array}{r}17836 \\
6.0\end{array}$ & $\begin{array}{r}185 \\
5.9\end{array}$ & $\begin{array}{r}585 \\
5.7\end{array}$ & $\begin{array}{r}374 \\
5.6\end{array}$ & $\begin{array}{r}9151 \\
5.8\end{array}$ & $\begin{array}{r}367 \\
5.9\end{array}$ & $\begin{array}{r}3484 \\
5.7\end{array}$ & $\begin{array}{r}1806 \\
5.7\end{array}$ & $\begin{array}{r}215 \\
6.1\end{array}$ & $\begin{array}{r}45270 \\
6.6\end{array}$ & $\begin{array}{r}52223 \\
7.0\end{array}$ & $\begin{array}{r}51596 \\
6.9\end{array}$ & $\begin{array}{r}47986 \\
6.1\end{array}$ & $\begin{array}{r}43286 \\
5.5\end{array}$ & $\begin{array}{r}39538 \\
5.1\end{array}$ & $\begin{array}{r}42727 \\
5.1\end{array}$ \\
\hline $\begin{array}{r}1287 \\
40.8\end{array}$ & $\begin{array}{r}52595 \\
40.5\end{array}$ & $\begin{array}{r}1432 \\
40.4\end{array}$ & $\begin{array}{r}97420 \\
40.6\end{array}$ & $\begin{array}{r}09281 \\
41.4\end{array}$ & $\begin{array}{r}24421 \\
42.0\end{array}$ & $\begin{array}{r}51349 \\
42.9\end{array}$ & $\begin{array}{r}50273 \\
45.1\end{array}$ & $\begin{array}{r}262711 \\
45.2\end{array}$ & $\begin{array}{r}16323 \\
46.2\end{array}$ & $\begin{array}{r}352607 \\
47.2\end{array}$ & $\begin{array}{r}366732 \\
48.7\end{array}$ & $\begin{array}{r}391442 \\
49.7\end{array}$ & $\begin{array}{r}398115 \\
51.0\end{array}$ & $\begin{array}{r}408332 \\
52.7\end{array}$ & $\begin{array}{r}450050 \\
54.2\end{array}$ \\
\hline $\begin{array}{r}35337 \\
5063 \\
8169 \\
3280 \\
3931 \\
6421 \\
8005 \\
51082\end{array}$ & $\begin{array}{r}43722 \\
6270 \\
9137 \\
3640 \\
4568 \\
8248 \\
11163 \\
65849\end{array}$ & & & & & & & & & & & & & & $\begin{array}{r}98324 \\
21674 \\
20402 \\
6451 \\
14883 \\
21487 \\
53280 \\
213550\end{array}$ \\
\hline $\begin{array}{r}43958 \\
14 .\end{array}$ & $\begin{array}{r}5954 \\
15 .\end{array}$ & 16.4 & $\begin{array}{r}7763 \\
16 .\end{array}$ & $\begin{array}{r}8055 \\
15 .\end{array}$ & 15 & 15.4 & 15.5 & 15.5 & 15.2 & 15.0 & 15.1 & 15.8 & 15.9 & $\begin{array}{r}113713 \\
14.7\end{array}$ & $\begin{array}{r}09401 \\
13.2\end{array}$ \\
\hline $\begin{array}{r}40308 \\
3643\end{array}$ & $\begin{array}{r}54716 \\
4829\end{array}$ & $\begin{array}{r}6733 \\
616\end{array}$ & $\begin{array}{r}7084 \\
678\end{array}$ & $\begin{array}{r}734 \\
71\end{array}$ & $\begin{array}{r}766 \\
78\end{array}$ & & & & & & & & & & $\begin{array}{l}90209 \\
19192\end{array}$ \\
\hline $\begin{array}{r}97445 \\
100.0\end{array}$ & 100.0 & 100.0 & 100.0 & 100 & 100.0 & 100.0 & 100 & 100 & 10 & 100.0 & 10 & 100.0 & 100 & $\begin{array}{r}775542 \\
100.0\end{array}$ & $\begin{array}{r}30548 \\
100.0\end{array}$ \\
\hline & & & & & & & & & & & & & & & \\
\hline & 2236 & 1401 & 6080 & 485690 & 2350 & 564623 & 32178 & 558058 & j58 187 & 711923 & 17952 & 956870 & 745860 & 744230 & \\
\hline
\end{tabular}

Table 1: UK gross value added at market prices by sector, 1979-1994, at 1990 prices

Source: Eurostat (1996) 


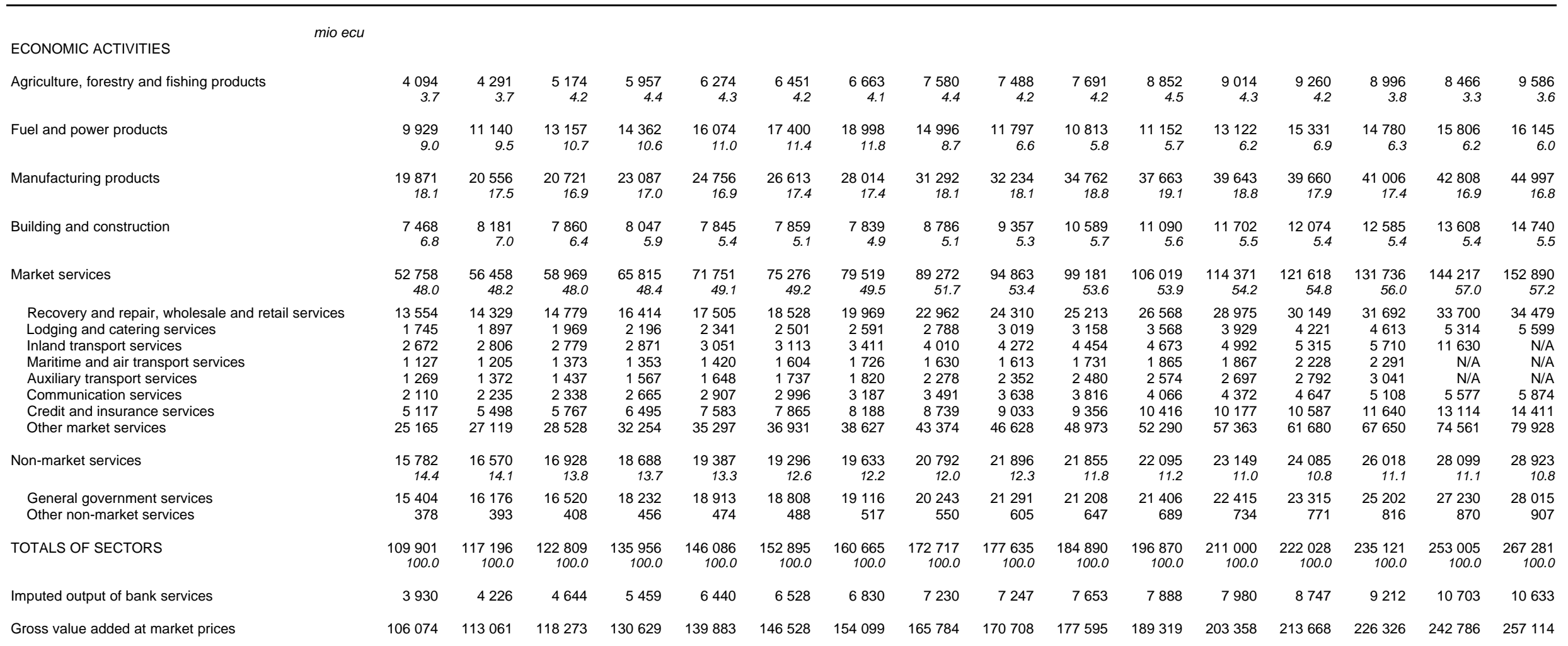

Table 2: Netherlands gross value added at market prices by sector, 1979-1994, at 1990 prices

Source: Eurostat (1996) 


ECONOMIC ACTIVITIES
Agriculture, forestry and fishing products
Fuel and power products
Manufacturing products
Building and construction
Market services
Recovery and repair, wholesale and retail services
Lodging and catering services
Inland transport services
Maritime and air transport services
Auxiliary transport services
Communication services
Credit and insurance services
Other market services
Non-market services
General government services
Other non-market services
TOTALS OF SECTORS
Imputed output of bank services
Gross value added at market prices

\begin{tabular}{|c|c|c|c|c|c|c|c|c|c|c|c|c|c|c|c|}
\hline $\begin{array}{r}12093 \\
2.3\end{array}$ & $\begin{array}{r}11767 \\
2.1\end{array}$ & $\begin{array}{r}12431 \\
2.1\end{array}$ & $\begin{array}{r}15042 \\
2.3\end{array}$ & $\begin{array}{r}14232 \\
2.0\end{array}$ & $\begin{array}{r}14973 \\
2.0\end{array}$ & $\begin{array}{r}13902 \\
1.7\end{array}$ & $\begin{array}{r}15492 \\
1.8\end{array}$ & $\begin{array}{r}14074 \\
1.5\end{array}$ & $\begin{array}{r}15806 \\
1.6\end{array}$ & $\begin{array}{r}17478 \\
1.7\end{array}$ & $\begin{array}{r}17444 \\
1.5\end{array}$ & $\begin{array}{r}16224 \\
1.3\end{array}$ & $\begin{array}{r}16243 \\
1.2\end{array}$ & $\begin{array}{r}14947 \\
1.1\end{array}$ & $\begin{array}{r}15148 \\
1.0\end{array}$ \\
\hline $\begin{array}{r}27028 \\
5.1\end{array}$ & $\begin{array}{r}27020 \\
4.8\end{array}$ & $\begin{array}{r}28599 \\
4.8\end{array}$ & $\begin{array}{r}32559 \\
5.0\end{array}$ & $\begin{array}{r}35226 \\
4.9\end{array}$ & $\begin{array}{r}37310 \\
4.9\end{array}$ & $\begin{array}{r}38821 \\
4.9\end{array}$ & $\begin{array}{r}41399 \\
4.7\end{array}$ & $\begin{array}{r}40127 \\
4.3\end{array}$ & $\begin{array}{r}41025 \\
4.2\end{array}$ & $\begin{array}{r}42651 \\
4.1\end{array}$ & $\begin{array}{r}44487 \\
3.9\end{array}$ & $\begin{array}{r}48603 \\
3.9\end{array}$ & $\begin{array}{r}52737 \\
3.9\end{array}$ & $\begin{array}{r}56509 \\
4.0\end{array}$ & $\begin{array}{r}57908 \\
3.9\end{array}$ \\
\hline $\begin{array}{r}167974 \\
31.5\end{array}$ & $\begin{array}{r}171032 \\
30.5\end{array}$ & $\begin{array}{r}175398 \\
29.7\end{array}$ & $\begin{array}{r}189582 \\
29.1\end{array}$ & $\begin{array}{r}208296 \\
29.1\end{array}$ & $\begin{array}{r}220306 \\
29.0\end{array}$ & $\begin{array}{r}237246 \\
29.8\end{array}$ & $\begin{array}{r}270325 \\
30.7\end{array}$ & $\begin{array}{r}283610 \\
30.5\end{array}$ & $\begin{array}{r}295534 \\
30.2\end{array}$ & $\begin{array}{r}310835 \\
29.9\end{array}$ & $\begin{array}{r}339603 \\
29.8\end{array}$ & $\begin{array}{r}360903 \\
29.0\end{array}$ & $\begin{array}{r}367601 \\
27.3\end{array}$ & $\begin{array}{r}353452 \\
24.9\end{array}$ & $\begin{array}{r}365341 \\
24.6\end{array}$ \\
\hline $\begin{array}{r}36957 \\
6.9\end{array}$ & $\begin{array}{r}41274 \\
7.4\end{array}$ & $\begin{array}{r}41387 \\
7.0\end{array}$ & $\begin{array}{r}42188 \\
6.5\end{array}$ & $\begin{array}{r}45306 \\
6.3\end{array}$ & $\begin{array}{r}46 \quad 194 \\
6.1\end{array}$ & $\begin{array}{r}43959 \\
5.5\end{array}$ & $\begin{array}{r}48557 \\
5.5\end{array}$ & $\begin{array}{r}50588 \\
5.4\end{array}$ & $\begin{array}{r}52436 \\
5.4\end{array}$ & $\begin{array}{r}56634 \\
5.4\end{array}$ & $\begin{array}{r}62749 \\
5.5\end{array}$ & $\begin{array}{r}67674 \\
5.4\end{array}$ & $\begin{array}{r}76274 \\
5.7\end{array}$ & $\begin{array}{r}79880 \\
5.6\end{array}$ & $\begin{array}{r}85749 \\
5.8\end{array}$ \\
\hline $\begin{array}{r}214361 \\
40.2\end{array}$ & $\begin{array}{r}229441 \\
40.9\end{array}$ & $\begin{array}{r}246012 \\
41.7\end{array}$ & $\begin{array}{r}276503 \\
42.5\end{array}$ & $\begin{array}{r}309880 \\
43.3\end{array}$ & $\begin{array}{r}335064 \\
44.0\end{array}$ & $\begin{array}{r}351090 \\
44.1\end{array}$ & $\begin{array}{r}281328 \\
43.3\end{array}$ & $\begin{array}{r}410074 \\
44.1\end{array}$ & $\begin{array}{r}438196 \\
44.7\end{array}$ & $\begin{array}{r}470975 \\
45.3\end{array}$ & $\begin{array}{r}525742 \\
46.1\end{array}$ & $\begin{array}{r}589419 \\
47.3\end{array}$ & $\begin{array}{r}654550 \\
48.6\end{array}$ & $\begin{array}{r}720621 \\
50.8\end{array}$ & $\begin{array}{r}763089 \\
51.4\end{array}$ \\
\hline $\begin{array}{r}60655 \\
7273 \\
11113 \\
2713 \\
4446 \\
12318 \\
23563 \\
92281\end{array}$ & $\begin{array}{r}61589 \\
7822 \\
11742 \\
2907 \\
4804 \\
12430 \\
25501 \\
102653\end{array}$ & $\begin{array}{r}62830 \\
8551 \\
12266 \\
3100 \\
5012 \\
13062 \\
29232 \\
111961\end{array}$ & $\begin{array}{r}67483 \\
9309 \\
13288 \\
2312 \\
5538 \\
14834 \\
35622 \\
127120\end{array}$ & $\begin{array}{r}74795 \\
10024 \\
14239 \\
3206 \\
6048 \\
16225 \\
40705 \\
144641\end{array}$ & $\begin{array}{r}80694 \\
10368 \\
15275 \\
3529 \\
6607 \\
17222 \\
42996 \\
158376\end{array}$ & $\begin{array}{r}81786 \\
10380 \\
15996 \\
3809 \\
6936 \\
17937 \\
43869 \\
170381\end{array}$ & $\begin{array}{r}88432 \\
11682 \\
16949 \\
3804 \\
7303 \\
19549 \\
45874 \\
187738\end{array}$ & $\begin{array}{r}93867 \\
12872 \\
17893 \\
8717 \\
7948 \\
20926 \\
46273 \\
206411\end{array}$ & $\begin{array}{r}98766 \\
13380 \\
18778 \\
4182 \\
8529 \\
22025 \\
49065 \\
223478\end{array}$ & $\begin{array}{r}103089 \\
14504 \\
20152 \\
4590 \\
9326 \\
23612 \\
52262 \\
243446\end{array}$ & $\begin{array}{r}119231 \\
16281 \\
22084 \\
4875 \\
10490 \\
24934 \\
55102 \\
272744\end{array}$ & $\begin{array}{r}136115 \\
17290 \\
23052 \\
5119 \\
11064 \\
27316 \\
63617 \\
305846\end{array}$ & $\begin{array}{r}142731 \\
18485 \\
24529 \\
5459 \\
12189 \\
39241 \\
72067 \\
348849\end{array}$ & $\begin{array}{r}146743 \\
19700 \\
25397 \\
5801 \\
12808 \\
32449 \\
83490 \\
394233\end{array}$ & $\begin{array}{l}\text { N/A } \\
\text { N/A } \\
\text { N/A } \\
\text { N/A } \\
\text { N/A } \\
\text { N/A } \\
\text { N/A } \\
\text { N/A }\end{array}$ \\
\hline $\begin{array}{r}74439 \\
14.0\end{array}$ & $\begin{array}{r}80407 \\
14.3\end{array}$ & $\begin{array}{r}86268 \\
14.6\end{array}$ & $\begin{array}{r}94689 \\
14.6\end{array}$ & $\begin{array}{r}102673 \\
14.3\end{array}$ & $\begin{array}{r}106885 \\
14.1\end{array}$ & $\begin{array}{r}111965 \\
14.0\end{array}$ & $\begin{array}{r}123497 \\
14.0\end{array}$ & $\begin{array}{r}132449 \\
14.2\end{array}$ & $\begin{array}{r}136322 \\
13.9\end{array}$ & $\begin{array}{r}140936 \\
13.6\end{array}$ & $\begin{array}{r}151401 \\
13.3\end{array}$ & $\begin{array}{r}163323 \\
13.1\end{array}$ & $\begin{array}{r}178501 \\
13.3\end{array}$ & $\begin{array}{r}193704 \\
13.7\end{array}$ & $\begin{array}{r}198718 \\
13.4\end{array}$ \\
\hline $\begin{array}{l}63277 \\
11162\end{array}$ & $\begin{array}{l}68209 \\
12198\end{array}$ & $\begin{array}{l}72985 \\
13283\end{array}$ & $\begin{array}{l}79710 \\
14979\end{array}$ & $\begin{array}{l}86119 \\
16555\end{array}$ & $\begin{array}{l}89247 \\
17638\end{array}$ & $\begin{array}{l}93012 \\
18953\end{array}$ & $\begin{array}{r}101927 \\
21571\end{array}$ & $\begin{array}{r}108911 \\
23538\end{array}$ & $\begin{array}{r}111672 \\
24650\end{array}$ & $\begin{array}{r}115169 \\
25767\end{array}$ & $\begin{array}{r}123280 \\
28121\end{array}$ & $\begin{array}{r}132153 \\
31170\end{array}$ & $\begin{array}{r}143758 \\
34743\end{array}$ & $\begin{array}{r}155372 \\
38331\end{array}$ & $\begin{array}{r}158403 \\
40315\end{array}$ \\
\hline $\begin{array}{r}532851 \\
100.0\end{array}$ & $\begin{array}{r}560940 \\
100.0\end{array}$ & $\begin{array}{r}590095 \\
100.0\end{array}$ & $\begin{array}{r}650563 \\
100.0\end{array}$ & $\begin{array}{r}715612 \\
100.0\end{array}$ & $\begin{array}{r}760722 \\
100.0\end{array}$ & $\begin{array}{r}796983 \\
100.0\end{array}$ & $\begin{array}{r}880598 \\
100.0\end{array}$ & $\begin{array}{r}930923 \\
100.0\end{array}$ & $\begin{array}{r}979319 \\
100.0\end{array}$ & $\begin{array}{r}1039509 \\
100.0\end{array}$ & $\begin{array}{r}1141425 \\
100.0\end{array}$ & $\begin{array}{r}1246045 \\
100.0\end{array}$ & $\begin{array}{r}1345905 \\
100.0\end{array}$ & $\begin{array}{r}1419112 \\
100.0\end{array}$ & $\begin{array}{r}1485953 \\
100.0\end{array}$ \\
\hline 19595 & 21469 & 25172 & 30985 & 35987 & 37563 & 37847 & 39325 & 39714 & 41048 & 42707 & 46918 & 54243 & 61409 & 68339 & 69933 \\
\hline 513256 & 539571 & 564923 & 619578 & 679624 & 723159 & 759136 & 841274 & 891209 & 938271 & 996802 & 1094508 & 1191802 & 1284496 & 1350773 & 1416021 \\
\hline
\end{tabular}

Table 3: German gross value added at market prices by sector, 1979-1994, at 1990 prices

Source: Eurostat (1996) 
